\title{
Consequences of (un)regulated party funding in South Africa between 1994 and 2017
}

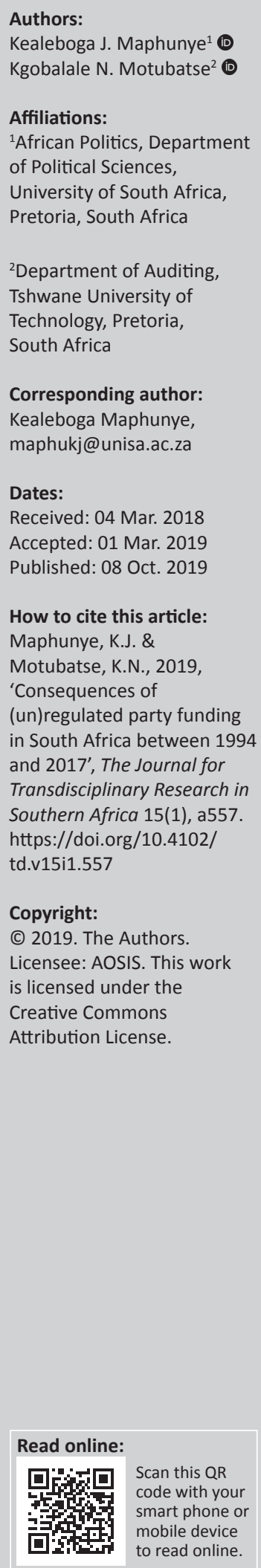

Globally, the topic of political party funding evokes strongly defended positions, partly because of the nasty dynamics that usually arise whenever money and politics cross paths. The primary issue in contention is whether to institute mandatory disclosure legislation, legally compelling parties to reveal their sources of funding, and the likely consequences of such disclosure. Alternatively, a laissez-faire approach may be adopted to party funding, and to determine which parties to exclude from state or public funding. In South Africa, these issues routinely raise public outcry and result in emotive debates pertaining to the expenditure of public finance and accountability. Thus, this article explores contemporary issues on political party funding in South Africa, focusing on recognised parties and examining their sources of funding. This article examines recent media reports on allegations of a lack of accountability on the part of political parties, particularly their apparent reluctance to disclose their sources of funding. It seeks to contribute to the debate on party funding in South Africa, through the use of a qualitative research method using content analysis. The authors contend that officially recognised parties should be audited by a Supreme Audit Institution (the Auditor General South Africa, locally) prior to tabling their annual reports in Parliament. The article concludes that such audit responsibility should not be given to private audit firms in order to avoid possible conflicts of interest, as some audit firms and individual employees may also be funders of some of the political parties.

Keywords: Political funding; public accountability; public interest; regulated funding; political parties.

\section{Introduction}

Since the advent of democracy in South Africa in 1994, there has been ongoing debate on the issue of political party funding, and the campaigns for public accountability and transparency have become an increasingly prominent preoccupation in the country's national discourse, especially during election campaigns. Initially, both governing and opposition parties seemed to be in agreement on this issue in that they were reluctant to disclose the sources of their funding. Whether this shared attitude was as a consequence of parties' ignorance of existing legislation or because of a more sinister, blatant disregard for ethical issues concerning party funding was difficult to determine. However, the recent public tussle between the political parties and one civil society body, the Institute for Democracy in South Africa (IDASA, which no longer exists), over access to funding data strongly suggested an inexorably negative trend whereby political parties increasingly embraced unethical funding practices. Despite this, since 2015 more parties seemed to be willing to disclose their sources of funding, possibly suggesting pressure from voters as South Africa approached the 2016 local government and 2019 national and provincial elections.

However, the continually revived public demands, that parties demonstrate financial transparency, have encouraged many civil formations and institutions to pressurise political parties to fully disclose their sources of funding. According to Rowbottom (2016), political party financing should be reviewed from a multiplicity of viewpoints, most importantly, their ethics, accountability, transparency and accessibility of information. Ethics plays a critical part in determining what political parties choose or choose not to do with respect to sourcing funding for their survival.

In terms of transparency, in a democratic society such as South Africa, the public expects parties to reveal their funding sources willingly and as a matter of course. Not only does this information enable them to know who funds (and thus potentially influences) such parties but it also allows the electorate to make better-informed choices about which party to vote for during elections. 
Among other viewpoints, transparency refers to the effort the public is required to make to gain access to information and records pertaining to such funding, should the information be required. In South Africa, the Public Access to Information Act (PAIA) (Republic of South Africa [RSA] 2000) serves as an enabling mechanism for such access. Ultimately, however, the positive aspects of the above factors depend on the degree to which public representatives such as parliamentarians believe they are accountable to party members and/or other interested individuals and organisations. They require someone to demonstrate the will and courage to promote their party's accountability through regular reporting, and the implementation of appropriate operational checks and balances.

This article therefore examines South Africa's present regulatory mechanisms governing political party funding. Globally, many regulations advocate that political parties be legally established and provide full financial disclosure and accountability underpinned by formal auditing processes. Nevertheless, within the limitations of the present South African regulations for establishing political parties, this article argues that the requirements regarding financial disclosure by political parties are inadequate. Further, because it has become the subject of public interest, especially for civil society and public and private media, political party funding in South Africa warrants systematic investigation.

In South Africa, there is a lack of effective and systematic control or regulation of the funding methods employed by political parties, and this remains sharply at odds with the country's attempts to entrench democratisation. This uneasy status quo is maintained by the apparent reluctance of both the governing African National Congress (ANC) and the opposition parties, including the official opposition, the Democratic Alliance (DA), to introduce effective controls over the funding of political parties. It must, however, be recorded that no empirical link has been demonstrated between the secrecy surrounding the funding of political parties and the presence of corruption (Sarakinsky 2007; Van Biezen 2010).

Nevertheless, the lack of support for such measures on the part of government, which includes the smaller opposition parties, largely discourages civil society's attempts to promote effective party funding regulations. Past research by IDASA on this subject has shown, ironically, that both the ANC and the DA were in agreement that there should be no disclosure of their particular sources of funding and that they actively opposed measures by civil society to force parties to become transparent (Daily Maverick 2017). This attitude suggested that parties wanted to operate without any controls or formal oversight, and largely below the radar of public scrutiny. Yet, some parties made rather credible arguments that funders or prospective funders of the ANC or opposition parties risked being targeted or penalised if their funding sources were to be disclosed. In addition, what complicates matters is the apparent reluctance on the part of the (mostly) silent party benefactors to reveal their identities, nor are they particularly forthcoming with assistance in efforts to effect checks and balances. In the absence of any voluntary transparency by the parties concerned (even from their benefactors), anecdotal evidence suggests that there are many business and other clandestine interests that support the big political parties financially, and speculation is rife as to the effects this has on South Africa's public policy formulation and implementation, and on corporate governance in general.

In terms of structure, the remainder of this article is arranged as follows: the next section examines the debates around party funding, followed by discussion on the literature review focusing on full disclosure as an accountability mechanism, relevance to governance in South Africa, public interest and regulated funding. The next section discusses the research method. Thereafter, there is a presentation and discussion of the results. The final section draws conclusions from the literature and current results and presents recommendations for further studies.

\section{Unpacking the debates on party funding}

At various South African institutions such as Corruption Watch and the Right2Know Campaign, the debates on political party funding have been rekindled by society's interest in the role of political parties and in their financial viability. However, within the recognised political parties, the members' understanding of 'accountability' with respect to their finances is apparently different from that of the general public; one hopes, mainly because of ignorance of the tools of proper governance and thus their non-compliance with them. Yet, owing to their unique nature, political parties cannot expect to be treated like non-profit organisations (NPOs), which are required simply to demonstrate their financial accountability in order to increase donations. The transparency and accountability of the organisations promote their reputations beyond their immediate operational spheres (RSA: Non-profit Organisations Act 1997). For political parties, their only legal basis in South Africa arises from provisions in the Constitution (RSA 1997: Section 19) that are supported by the Electoral Commission ${ }^{1}$ of South Africa, which is the organisation tasked with managing political parties' participation in the various elections identified in Section 26 of the Act.

Within the recurring debates about the state of funding of political parties, there is one question that citizens seem particularly interested in: 'Who are their private funders?' (Right2Know 2015). This question has been (and continues to be) addressed in formal academic research in the field of politics, as part of ongoing attempts to discover and explain relations between political parties and their sources

1.In terms of Chapter 9 of the Constitution, South Africa's election management body is formally known as the Electoral Commission, but it is popularly known body is formally known as the Electoral Commission, but it is popularly known
as the 'Independent Electoral Commission' (IEC). These two names are used as the 'Independent Electoral
interchangeably in this article. 
of funding (Kotze 2004; Pinto-Duschinsky 2002; Primo 2013; Robinson \& Brummer 2006). These writers' research findings are fundamentally similar and identify various means of corrupting the process; they also identify deficiencies in ethics and highlight transparency issues manifesting as discrepancies between disclosed party funding and their (parties') spending patterns.

\section{Literature review}

\section{Political party finances}

In a representative democratic system such as South Africa's, the cardinal principles of public finance apply. Among these is the '... principle of responsibility and accountability of the elected political representatives to the taxpayers for the collection and spending of taxes and other income' (Gildenhuys 1993:55). The funding of established political parties is also covered by such principles, which serve as the bedrock of public finance. More than three decades ago, it was argued that public finance rested on administrative efficiency, among others (Prest \& Barr 1985:147). In other words, public income and expenditure require administrative efficiency to enable a system of government to function optimally, and this applies in the allocation of funds to institutions such as political parties. Thus, they are reasonably expected to account for the expenditure of the money allocated to them by Parlement by producing annual statements and reports that national and provincial legislatures and other interested and affected bodies could then subject to rigorous scrutiny; this should be no different from the requirements enforced on other public entities that receive such allocations from National Treasury.

However, recent published research on party funding suggests that political parties' finances are not far from scandalous (Mataković \& Petak 2015). According to PintoDuschinsky (2002:69), political party finances include 'money to be spent on direct political purposes such as campaign expenses, costs of maintaining research, engaging in political education, voter registration and other functions'. Thus, in the past 5 years, the Electoral Commission of South Africa (IEC)'s allocations to all political parties represented in the National Assembly and provincial legislatures have been increasing both in response to inflation and proportionally, reflecting changes in the number of parties in Parlement.

Table 1 shows that the IEC has distributed from the public purse in excess of R575 million (1 US dollar is approximately

TABLE 1: Depicts an increasing allocation per annum.

\begin{tabular}{llcc}
\hline Number & Year & $\begin{array}{c}\text { Amount } \\
\text { allocated (Rand) }\end{array}$ & $\begin{array}{c}\text { Represented } \\
\text { political parties }\end{array}$ \\
\hline 1. & 2012 & 103900782 & 14 \\
2. & 2013 & 108236911 & 14 \\
3. & 2014 & 114811165 & 14 \\
4. & 2015 & 121451110 & 15 \\
5. & 2016 & 127394146 & 15 \\
\hline
\end{tabular}

Source: Independent Electoral Commission's annual reports on Represented Political Parties Funds (2012-2016)

Note: Amounts in South African rand. equal to 15 SA rands) in the last 5 years. This is a significant sum, fully justifying demands that its recipients be subject to an annual audit as a way of improving accountability in the broader public sector. Of course, political parties are quick to champion the cause of transparency and good governance in the interest of democracy when someone else's spending habits are being scrutinised. They are less keen to have their own finances subject to similar scrutiny. To emphasise the point: an audit should be done in all instances where funds are received or allocated from the public purse, as this would increase transparency and encourage public confidence in these institutions. It is also hoped that this disclosure and scrutiny of the way these public funds have been used may also encourage the parties to become more principled and ethical in their personal administration.

Agreeing with this view, Primo (2013) emphasises that political parties should reveal their funding sources and how they have spent their monies. Furthermore, the civil society group Right2Know Campaign (2015) argues that if political parties' finances are not fully shown, this promotes the use of the 'secret space' between politicians and their financiers, which undermines democracy. In South Africa, the debate about who funds political parties has come to the fore because political parties have failed to reveal all the sources of their funds, encouraging Ellis (2000:52) to state that this culture of secrecy needs to be counteracted with the implementation of far more transparent systems. However, this is easier said than done, as the country never experienced a democratically reviewed public financial system before 1994. When the country finally adopted democratic systems in 1994, there was very little time for the newly legalised parties to familiarise themselves with the principles of accountability in a democracy, principles that underpin effective public financial administration. This probably accounts for some of the post-democracy controversy the country has encountered whenever the idea of regulating political party funding has been raised.

Robinson and Brummer (2006) stress that a lack of transparency in any government sector undermines the national government's efforts to promote the implementation of sound governance principles; furthermore, it is fundamental to the South African systems of governance that any and all public organisations should be subject to public scrutiny. In a study conducted by Rowbottom (2016) investigating corruption, transparency and reputation, it was found that there is an increasing level of concern about political parties' finances and the exercise of undue influence on them. Thus, the funding of political parties is a problem as this is beyond the jurisdiction of current regulations (Kotze 2004; PintoDuschinsky 2002). Of course, more specifically, the effective regulation of political funding might also uncover information that could compromise politicians' credibility (Gilbert 2012). Thus, in compliance with regulation, political parties would be expected to regularly disclose and identify their sources of income and financial support received from legal (and illegal) dealings (Gilbert \& Aiken 2015:153). 
As numerous scholars have argued:

$\ldots$ one of the most cardinal values of democracy is that all activities regarding public financial management and administration must take place in public, and not under cover of secrecy or so-called confidentiality. (Gildenhuys 1993:55-56)

Such transparency is intricately linked to accountability. In a more specific sense, accountability requires organisations to disclose their financial statements and include all pertinent data (Li, Song \& Zhang 2014). Although the South African political parties do not fully disclose their financial information (Maphunye 2017), Kahl and Belkaoui (1981) argue that disclosure serves as an important means of communication between the users of the funds and their suppliers or donors. The importance of financial disclosure is such that, in general, it is the one area that needs greater regulation (Potter 2015). Political party funding in South Africa is largely free of regulation, and globally some argue that mandatory disclosure is an appropriate form of regulation to shape the organisation's financial reporting (Franke \& Zhang 2016). Nevertheless, it remains only as a hope that mandatory disclosure might reduce corruption (Potter 2015). Whether this would be sufficient, however, is debatable and we need to tread with caution here, given relatively recent claims that '[m]any people believe that widespread political corruption exists in South Africa' (Lodge 1998:157). Such claims were based on an earlier Institute for Democracy in South Africa (IDASA) Public Opinion Survey as well as figures from the World Value Survey. In the light of the more recent 'state capture' events, the situation has not apparently improved.

\section{Full disclosure as an accountability mechanism}

Full disclosure presupposes accountability and transparency, based on a widely shared code of ethics (Jordan et al. 2017). Disclosure increases efficiency (Leuz \& Wysocki 2016), and it is essential to accountability as it reflects compromise-free adherence to the rules of governance (Nelson 2001).

According to Zhang (2015), full disclosure is arguably one of the most important institutional features that shapes accountability, while a policy of radical disclosure encourages transparency (Kasekende, Abuka \& Sarr 2016). Full financial disclosure requires that all material information has to be disclosed in the financial statements (Ball, Jayaraman \& Shivakumar 2012; Leuz \& Wysocki 2016). In a study examining the value and relevance of International Financial Reporting Standards' (IFRS) mandatory disclosure requirements, Tsalavoutas and Dionysiou (2014) found that mandatory full disclosure encourages more transparent financial reporting patterns. Further, Wehner and De Renzio (2013) found that there is a direct and significant relationship between budgetary disclosure and financial transparency. However, Berliner (2014) maintains that politicians have many reasons to resist transparency and this has been particularly evident in the South African political environment. A key reason is the probability or fact that some funders demand anonymity as they are directly linked to and/or are beneficiaries of government expenditure projects. It is thus 'difficult' for South African political parties to adopt and maintain policies that advocate financial and operational transparency. Similarly, as the country's legislated requirements are somewhat deficient, and rarely enforced, opposition parties are also currently not obliged to reveal their sources of funding, and this calls into question as to their independence and objectivity.

Despite the widespread acceptance that political parties are autonomous organisations, exempt from running their affairs in accordance with the country's legislated financial frameworks, there is nevertheless an enormous need for them to disclose their financial information. Notwithstanding the annual reviews produced by the country's Electoral Commission on political party funding, individual parties' disclosure of their financials is still viewed by many interested users of financial statements as being of great importance to transparency and accountability, and far more informative than the limited information disclosed in the IEC's annual reports (IEC 2016). Compared with the probable costs of the actual activities and functions hosted by political parties during their electoral campaigns, the Electoral Commission's annual reports reflect a substantially smaller financial turnover and thus a lower disclosure threshold on the part of registered parties. In order for any worthwhile information to emerge from these reports, full financial disclosure is necessary (Schneider \& Scholze 2015). Clearly, the preferred or best option is full financial disclosure because it provides all the information that is subject to audit. Moreover, while a full audit might be 'inconvenient', the central purpose of an audit is to enhance the credibility and the public image of a political party by demonstrating their ability to comply with corporate governance frameworks in South Africa.

\section{Relevance to governance in South Africa}

One of the main responsibilities of any public agency is to be accountable to the people whom it serves in terms of legislation governing public institutions in South Africa. Despite the apparently ubiquitous academic focus on governance within political parties (and the interest has spread way beyond academia), many of the debates about issues arising from political party funding stem from the discovery (or suspicion) of corruption (Bryan \& Baer 2005). Governance is seen from both a public perception and a business perspective in politics and policy studies as serving as a form of accountability and responsibility framework that has the authority arising from being enforceable under the country's laws. Over the past two decades, discourse on good governance in South Africa has increasingly occurred in the party political and public spaces, especially since the governing party recalled former President Thabo Mbeki and replaced him with Jacob Zuma at the party's 2007 national conference in Polokwane. In the midst of the ongoing governance debates, public accountability has been acknowledged as a central issue, but it still remains an incomprehensible concept to the majority of rank and file 
members of political parties (Van Belle \& Mayhew 2016). Thus, there is justification for the view held by supporters of good governance that politicians talk about the right things but prefer to do the opposite (Daily Maverick 2017). Arguably, if appropriate legislation existed in terms of which political parties' finances were managed and regulated in compliance with legislation similar to, say, the Non-Profit Organisation Act 71 of 1997 (which requires, in terms of Section 17(1)(a) that 'every registered non-profit organisation must, to the standards of generally accepted accounting practice - keep accounting records of its income, expenditure, assets and liabilities'), transparency and credibility would be significantly enhanced. Such mandatory compliance would place a significant responsibility on the parties to account for all transactions and require the preservation of supporting vouchers, records of subscriptions or levies paid by its members, income and expenditure statements, balance sheets and accounting officer's reports for the prescribed accounting periods (RSA 1997).

The legal process for the establishment of political parties in South Africa is described in Section 19(1) of the Constitution, under the Bill of Rights. Accordingly, political parties are required to register with the Electoral Commission in order to operate and to participate in the elections (see the Electoral Commission Act 51 of 1996, ss. 15-17). These provisions prescribe the Electoral Commission's registration requirements and pre-conditions, which include divulging their names, symbols or emblems, abbreviations or acronyms, and constitutions, among others. Only after these have been received and scrutinised will the political party be issued with a formal proof of registration certificate. According to O'Regan (2010), in most circumstances political parties are viewed as voluntary associations in South African law. A voluntary association is characterised by separate legal personality, perpetual succession (where the changes in the identity of its members do not affect its existence), the ability to own property apart from its members and the lawful pursuit of gain or profit for itself or its members. However, political parties are obviously different from ordinary and apolitical voluntary associations: political parties are uniquely focused on maximising political influence and their operational methodologies are largely informed by their ideological underpinnings, politico-historical origins and present-day party political dynamics that are in turn heavily influenced by the political preferences of their (senior) members.

\section{Public interest}

Public interest in political parties stems from the notion that the public and political parties are interlinked and that they rely on each other for survival (Norris \& Van Es 2016). Thus, on the platform of public interest, the importance of the audit (if clean) is that it offers confidence in the financial affairs of political parties. Such confidence underpins and enables the development of trust and accountability between the public and political parties, and their policies and activities. Admittedly, there is a tenuous link between these two variables, as can be seen in the recurring and often violent community flare-ups (usually labelled 'service delivery protests') and other public demonstrations during which community members vent their frustration and anger at unaccountable public representatives such as local government councillors. South Africa's proportional representative system may be responsible for this malaise as the public representatives are seen as accountable to their political parties, rather than to the communities whom they have been directed to serve.

Despite the importance that public interest places on it, accountability is hard to come by in such a political environment (Chelimsky 2007). In the South African context, requiring that an audit be undertaken for accountability purposes and to increase the public's confidence in a political party is often difficult to achieve, partly because of the quality of financial literacy among members of the political parties that would be subject to such audits. Norris and Van Es (2016) state that political party finances worldwide vary greatly in quality and reflect the different national attitudes and levels of public interest in accountability.

Auditing political party finances might reduce public concerns and speculations regarding large and improper donations that the public often perceives to have been given for unethical and anti-democratic purposes. Interestingly, there is not a single political party in South Africa that has ever publicly discussed and/or disclosed its financial viability, nor have the results of an audit of a political party officially been made public, which is in stark contrast with the situation regarding audits of government departments and institutions. As a matter of speculation, it would be very interesting to see how political parties cope with a similar level of accountability and whether this would improve their accountability to their constituencies. ${ }^{2}$

Political parties' formally audited financial statements would add a degree of truth and transparency to the electoral process: there is nothing quite like making the audit reports and financial records of parties available to public scrutiny to change their behaviour. Besides increasing the electorate's confidence in political parties, such statements also facilitate decision-making as they demonstrate the levels of financial and fiduciary competence of the parties. Based on this, the public could decide on a basis of fact whether to continue to entrust the political parties with the handling of the nation's finances. Indeed, in South Africa legislation regulating the auditing profession and processes is robust enough to increase public confidence significantly. Such legislation includes the Public Audit Act 25 of 2004, which gives the Supreme Audit Institution (the Auditor General South Africa [AGSA]) the right and obligation to audit the finances of public entities and government departments, thereby ensuring the application of the principles of transparency (RSA 2004). Again, passing legislation requiring political

2.South Africa's proportional representation (PR) electoral system makes it easier for parties to avoid accounting to their 'constituencies' as the party list used by political parties to avoid accounting to their 'constituencies' as the party list used by political
parties usually makes public representatives more accountable to their own parties rather than the electorate. 
parties to comply with auditing legislation pertaining to government (political parties would be audited and required to fully disclose their finances) is one approach that could enhance public accountability and improve governance within political parties. The current state of affairs is such that only the portion of political party funding that comes from the Electoral Commission is audited by the AGSA. Political parties are thus complying with the letter of the Electoral Commission's regulations by appointing a registered auditor to audit their books and records of account for monies allocated to them from the fund, in terms of the provision of the Represented Political Parties' Fund Act (Act 103 of 1997, Section 6.)

Overall, however, as is the case in trying to define and act in 'the national interest', the concept of 'the public interest' is equally difficult to quantify and act upon, especially in the case of political parties and their funding in South Africa.

\section{Regulated funding}

According to the Independent Electoral Commission (2016), political parties may be funded by both public and private organisations and individuals. While the funding received from the IEC is well regulated and easily defined, there are no regulations whatsoever guiding the private funding of political parties. It is obvious that regulation increases good governance, as it enhances transparency. Gherghina and Volintiru (2017) point out that healthy political finances, if strictly regulated, can be equally healthy for a political system. It is thus somewhat ironic that, while all political parties are able to comply with Section 6 of the Represented Political Parties Act of 1997 (which requires political parties to act in an accountable and transparent manner with regard to the funds allocated to them by the IEC), these political parties are unable to extend the process to cover their 'private' funding and its uses.

\section{Research methodology \\ Content analysis}

The research methodology employed in this article includes content analysis and a review of recent literature on the topic. Although content analysis is considerably different from other qualitative methods of data collection and analysis, its advantage is its ability to support various research methods. Thus, content analysis may be used either in qualitative or quantitative research contexts (Elo \& Kyngäs 2008). However, its strength is that it gives attention to the meaning (Hsieh \& Shannon 2005) or interpretation of phenomena. It is a detailed method, and its procedures examine words and phrases and content meaning in most forms of communication (DowneWamboldt 1992; Hsieh \& Shannon 2005). The objective of this article is to analyse the content of media reports during South Africa's past two election cycles (2014 and 2016) with respect to issues pertaining to party funding, in order to determine and examine the trends. South Africa's fifth post-apartheid national elections were held during 2014, and its fourth local government elections were held in 2016. During these two election cycles, much was said on the funding of parties by a variety of role players, political parties and members of the public. Thus, this article tackles the following key questions:

- What is the central contentious issue about political party funding in South Africa?

- How has the issue been tackled in the electronic, print other media platforms?

- What kind of solutions have been proffered to resolve the contentious aspects of political party funding in the country?

Given that all of the above issues have been addressed in media reports, newspaper articles and other formal media statements, the employment of the content analysis approach as a research method was deemed appropriate. The next section of this article examines the main themes identified in various media on political party funding in South Africa.

In one online media article, the question asked by political commentator Judith February was: who is funding South Africa's political parties, and why do South Africans not know about this? (Daily Maverick 2016). The implied statement was that most of the political parties' expenses are not reflected in their public records.

Another recent article, this time in the national weekly, the Mail \& Guardian (2015), appeared under the headline 'Sources of party funding to remain private-court rules'. It was reported that a local non-profit organisation, My Vote Counts (MVC), 'has called on all political parties to start working on legislation that would force them to disclose information about their funding'. Clearly, as this issue had already progressed through the court system, it suggests that civil society organisations are attempting to exert more pressure on political parties to reveal all their funding sources. However, in terms of current legislation this cannot be compelled, and as South Africa's political system is dominated by a single party, the governing $\mathrm{ANC}$, it is in their interest that the system remains unchanged, thus improving their results at each major election. Thus, as long as the ANC retains a convincing majority in Parliament, it can continue to reject and defeat opposition votes to reform party funding practices and legislation.

According to the ANC's former head of elections during the recent local government polls, Nomvula Mokonyane, the ANC spent R1 billion on the 2016 local government elections (Daily Maverick 2016), an embarrassing revelation that the newspaper later denied. Another civil society watchdog, Corruption Watch (2016), also recently raised concerns that financial information from political parties and individual candidates was not being disclosed to the public. This also indicates that pressure is mounting from civil society and is echoed by other role players in the greater election arena, who increasingly question the status of political party funding in South Africa. Whether, and to what extent, such pressure will actually disturb the status quo and result in tangible action from Parliament is difficult to determine. However, the regular expression of such concerns in the country's national discourse 
might also indicate a slowly maturing democracy in which individuals and civil society associations are seen to be participating in issues of national and/or public concern.

\section{Discussion and analysis}

South African political parties are only publicly accounting for their income and expenditures with respect to the grant received from the Electoral Commission. Of much greater significance is the requirement that political parties' audited financial statements are supposed to form part of (or contribute data to) the annual reports prepared by the Electoral Commission. Thus, a review of the reports emerging after the 2016 local government elections suggests that the spending trends of political parties were high. Thus, Table 2 presents the IEC's spending allocation per represented political party for the past 2 years (list is alphabetical).

While the above data reflect the official positions of parties with respect to their use of IEC allocations, recent investigative journalist revelations show that the ANC spent a reported R1bn (IEC allocation for 2016: R75.6m) in the recent local government election campaign, the DA spent R350m (IEC allocation for 2016: R27.6m) and the EFF spent just less than R10m (IEC allocation for 2016: R10.3m) (News24 2016). The formula for calculating the percentage increase is as follows (TutorVista.Com 2017):

Formula for $\%=\frac{\text { Current year amount }- \text { Previous year amount }}{\text { Curent year amount }} \times \frac{100}{1}$ increase Current year amount

[Eqn 1]

There was an increase of $4.17 \%$ in $2013,6.07 \%$ in $2014,5.47 \%$ in 2015 and $4.67 \%$ in 2016. The average annual increase is $5.10 \%$. Thus, these increases are approximately in line to cover the cost of target inflation set by the South African Reserve Bank at $6 \%$. The increase in the amount spent was consistent with the increase of the represented parties from 2015.

TABLE 2: Spending allocation per represented political party from Independent Electoral Commission.

\begin{tabular}{lcc}
\hline Represented party & $\begin{array}{c}\text { Spending allocation } \\
\text { 2015 (Rand) }\end{array}$ & $\begin{array}{c}\text { Spending allocation } \\
\text { 2016 (Rand) }\end{array}$ \\
\hline African Christian Democratic Party (ACDP) & 823343 & 863632 \\
African Independent Congress (AIC) & 823343 & 863632 \\
Agang South Africa & 263388 & 276276 \\
African National Congress (ANC) & 72131024 & 75660653 \\
African People's Convention (APC) & 131694 & 138138 \\
Bushbuckridge Residents Association (BRA) & 343527 & 360337 \\
Congress of the People (COPE) & 1644558 & 1725032 \\
Democratic Alliance (DA) & 26301521 & 27588549 \\
Economic Freedom Fighters (EFF) & 9839775 & 10321270 \\
Freedom Front Plus & 1779077 & 1866133 \\
Inkatha Freedom Party (IFP) & 3422841 & 3590333 \\
Minority Party & 508287 & 533159 \\
National Freedom Party (NFP) & 1956920 & 2052679 \\
Pan Aficanist Congress (PAC) & 131694 & 138138 \\
United Democratic Movement (UDM) & 1350118 & 1416185 \\
\hline Total allocation per annum & $\mathbf{1 2 1 4 5 1 1 1 0}$ & $\mathbf{1 2 7} 394146$ \\
\hline
\end{tabular}

Source: Independent Electoral Commission annual reports on Represented Political Parties Funds (2015-2016)

Note: Amounts in South African rand.
It remains our contention that full disclosure financial reporting enhances good governance, and by extension, it forms part of ongoing efforts to improve public governance and accountability in political party finances. Obviously, a mandatory requirement of full financial reporting disclosure may affect political parties' supporters' preference for confidentiality, should they disclose their sources of funds. From the point of view of political parties, a possible negative outcome of such disclosure could be the loss of current or prospective support from influential members afraid of publicly endorsing one (or many) political parties.

Yet, such disclosures would further inform the wider voting public and prospective party members about the influence being exerted on parties' activities and financial health by wealthy supporters; the outcome of such transparency on prospective supporters is difficult to predict with any certainty. Thus, while full financial disclosure is undoubtedly highly informative (Hassanein \& Hussainey 2015), the more formal but less informative disclosures under the IEC's present system offer very little insight into the workings of individual political parties (Carvalho, Rodrigues \& Ferreira 2016).

On 28 March 2014, political analyst Judith February told Talk Radio 702's John Robbie that '... the secrecy [surrounding]

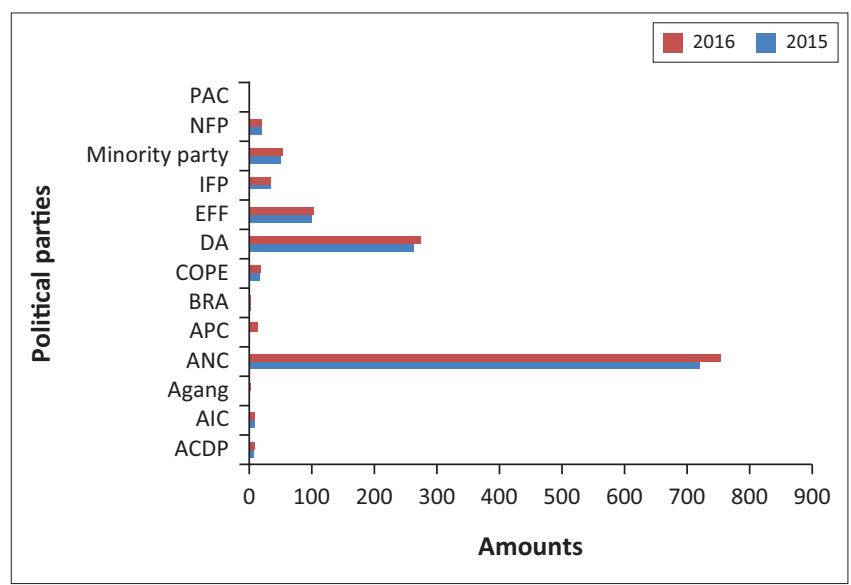

PAC, Pan Aficanist Congress; NFP, National Freedom Party; IFP, Inkatha Freedom Party; EFF, Economic Freedom Fighters; DA, Democratic Alliance; COPE, Congress of the People; BRA, Bushbuckridge Residents Association; APC, African People's Convention; ANC, African National Congress; Agang, Agang South Africa; AIC, African Independent Congress; ACDP, African Christian Democratic Party.

FIGURE 1: Spending allocation.

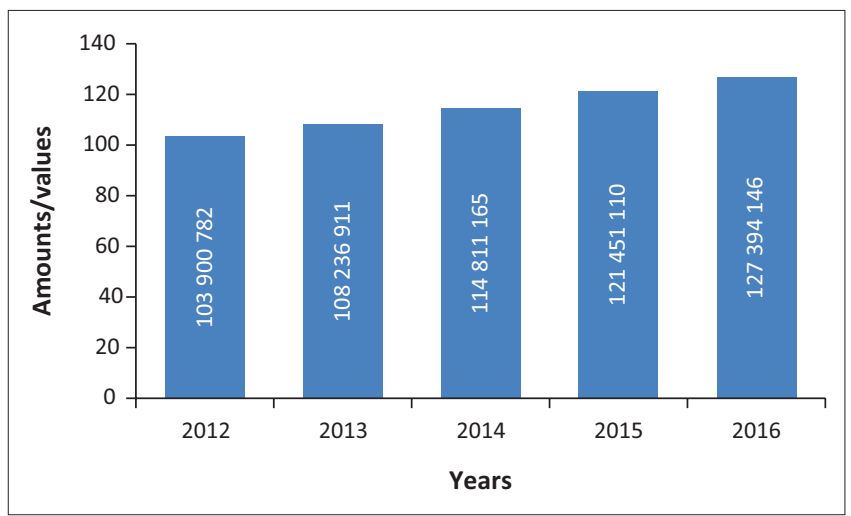

FIGURE 2: Annual amounts allocated - Percentage increases. 
funding for political parties should be scrutinized as a matter of urgency to allow transparency ...'. In another interview with the same radio station, Maphunye noted:

\begin{abstract}
... it is interesting to see that these political parties were audited individually by different audit companies/firms. But what remains is that the Auditor General has a legislative mandate to audit the IEC as an organ of the state.

Whereas, the individual parties are not obliged to have their books and records reviewed or audited by the Auditor General, because they are not accountable to the public as would be the case with government departments and public bodies. However, there is no piece of legislation in South Africa that may cause the political parties to account for their finances. (Maphunye 2018:n.p.)
\end{abstract}

Notwithstanding the fact that many researchers hold similar views regarding party political funding, Berkowitz (2013) argues that 'it is crucial for political parties to receive money [from the state] to finance their campaign, policy research and general administration'. Phosa (2012) warns that while political parties need funding to operate, they would not take money from the criminals as this may lead to corruption and abuse.

\section{Conclusion and recommendations}

This article has analysed the state of financial affairs regarding political parties' funding in South Africa.

The findings indicate that there is a need for more inclusive regulation of political parties' finances. Such regulations should obligate political parties to adhere to the good governance practices of accountability and transparency out of respect for their supporters and the country's citizens in general. In particular, the article reveals that the subject of political parties' sources of funding in South Africa remains shrouded in secrecy, and it is cold comfort that the country is probably not be alone in this regard, as the issue of transparency in political party funding evokes similarly negative responses globally. The consequence is that citizens and voters remain essentially clueless about who donates to the parties; what their motives are; the degree to which such funding exerts any influence on the way parties behave; and whether they are in power or opposition. The heated debates centred on allegations of 'state capture' in South Africa came to a head in 2016-2017. That the situation has arisen might well be associated with what we contend are party funding issues that have remained unresolved since the advent of the country's democracy. It is our contention that because political parties have not been required or compelled to comply with disclosure requirements at least as stringent as those required by the Public Finance Management Act, the Companies Act and/or the provisions of the King Reports on Corporate Governance, among others, an opportunity to improve political parties' accountability to their donors and supporters has yet to be realised.

Nonetheless, disclosure is a critical aspect of any political party's finances, largely because it encourages transparency and this assures the public that whatever funding is received by parties is legitimate and applied to legitimate programmes. In any public finance management system, legislation includes the requirement that proper audits are performed annually. However, in the case of South African political parties, the performance of 'proper audits' according to legislation is not sufficient, as this only covers monies received from the state. If the parties themselves prefer not to be transparent or accountable to anyone with respect to privately obtained funding, and do not institute corporate governance best practices, then any such audit that they do submit to is little more than a 'tick-box' compliance issue that defeats the purpose of an audit. Addressing this situation, it is recommended, would require legislation that compels all political parties that are represented in Parliament to table their complete annual reports in the National Assembly and that the underlying financial statements should be audited by the AGSA, the country's Supreme Audit Institution. Retaining this oversight responsibility in government would eliminate the risk that occurs when private audit firms conduct audits of political parties, as they (both as business entities and through the individual preferences of their staff and directors) are also funders of the country's political parties.

Since there is as yet no legislation that regulates the flow of private donations to fund political parties, this article recommends that such regulations be developed to manage the balance required between transparency and private donors' fears of possible negative reactions to their political preferences becoming public knowledge. The authors also recommend that private donors should be incentivised to insist on transparency from their preferred political parties by the introduction of tax benefits arising from those donations. It is further suggested that the Electoral Commission reviews its funding model for political parties, perhaps by setting a higher minimum allocation that would enable particularly the smaller parties to enjoy greater popular exposure as a result of being able to afford more effective advertising campaigns and more extensive research.

Although legislation is already in place (political parties already submit their financial statements to the Electoral Commission), such financial statements only account for the monies granted to them by the Commission. We again recommend that audits be performed on political parties' entire sets of financial transactions, regardless of the source of funds, and that this audit should be performed by the AGSA, thereby increasing the public's and civil society's confidence in such reports. Although no comprehensive, mandatory audit requirements currently exist for South African political parties, this could change soon. There are apparently, at the time this article was being compiled, plans for Parliament to debate the issue of party funding. Thus, the opportunities exist for future research to examine other parameters that would come into play should the disclosure of voluntary donations become mandatory; in addition, as the intention of such legislation would be to boost ethical practices, good governance and transparency in relation to 
party funding in South Africa, future research could examine the degree to which these objectives have been achieved.

\section{Acknowledgements}

The authors acknowledge the cooperation and assistance of the Electoral Commission of South Africa in obtaining the relevant information on political party funding on which this article is based. They also acknowledge the inputs and advice of the two anonymous reviewers whose insightful comments resulted in significant improvements in its quality. The authors are grateful for their comments.

\section{Competing interests}

The authors have declared that no competing interests exist.

\section{Authors' contributions}

K.J.M. worked with the co-author to conceptualise and develop the final title, argument and layout of the article; verified and added literature on South Africa's elections; and relevant documentation by the Electoral Commission of South Africa. K.N.M. collected and analysed finance-related documents and created all the figures and tables. He also developed arguments for and against current practice on the funding of political parties, supplied additional relevant legislation and assisted in the editing of the pre-submission version of this article.

\section{Funding information}

The authors declare that this research was not funded by any other individual or institution.

\section{Data availability statement}

Data sharing is not applicable to this article as no new data were created or analysed in this study.

\section{Disclaimer}

The views and opinions expressed in this article are those of the authors and do not necessarily reflect the official policy or position of any affiliated agency of the authors.

\section{References}

Ball, R., Jayaraman, S. \& Shivakumar, L., 2012, 'Audited financial reporting and voluntary disclosure as complements: A test of the confirmation hypothesis' Journal of Accounting and Economics 53(1), 136-166. https://doi.org/10.1016/ j.jacceco.2011.11.005

Berkowitz, P., 2013, SA party financing: Show us the money, viewed 21 January 2017, from https://www.dailymaverick.co.za/opinionista/2013-01-17-sa-party-financingfrom https://www.dailymaverick.co.za/

Berliner, D., 2014, 'The political origins of transparency', The Journal of Politics 76(2), 479-491. https://doi.org/10.1017/S0022381613001412

Bertomeu, J. \& Magee, R.P., 2015, 'Political pressures and the evolution of disclosure regulation', Review of Accounting Studies 20(2), 775-802.

Bryan, S. \& Baer, D., 2005, Money in politics: A study of party financing practices in 22 countries, National Democratic Institute, Washington, DC.

Carvalho, C., Rodrigues, A.M. \& Ferreira, C., 2016, 'Goodwill and mandatory disclosure compliance: A critical review of the literature', Australian Accounting Review 26(4), 376-389. https://doi.org/10.1111/auar.12129
Chelimsky, E., 2007, 'On fulfilling the accountability purpose of audit and evaluation: Integrating politics and public involvement', in Auditing for social change: A strategy for citizen engagement in public sector accountability, p. 115, United strategy for citizen engagement in public stions, New York. ST/ESA/PAD/SER.E/75.

Constitution of the Republic of South Africa, 1996, Government Printers, Pretoria.

Corruption Watch, 2015, Political parties: The missing link in our constitution?, viewed 12 December 2016, from http://www.corruptionwatch.org.za/political-partiesthe-missing-link-in-our-constitution/.

Corruption Watch, 2016, Cleaning up political party funding, viewed 12 December 2016, http://www.corruptionwatch.org.za/cleaning-political-party-funding/.

Daily Maverick, 2016, Who is funding our political parties, and why don't we know?, viewed 12 December 2016, from https://www.dailymaverick.co.za/opinionista/ 2016-08-01-who-is-funding-our-political-parties-and-why-dont-we-know/\#. WE6XIM8aL4Y.

Daily Maverick, 2017, The time has come for years of inaction around funding of political parties to turn to action, viewed 13 September 2016, from https://www. dailymaverick.co.za/opinionista/2017-05-19-the-time-has-come-for-years-ofinaction-around-funding-of-political-parties-to-turn-to-action/\#.WbIVSLljHIU.

Downe-Wamboldt, B., 1992, 'Content analysis: Method, applications, and issues' Health Care for Women International 13(3), 313-321. https://doi.org/10.1080/ 07399339209516006

Electoral Commission Act (51 of 1996) \& Regulations, Juta, Cape Town.

Ellis, R., 2000, 'Political party funding in South Africa', Doctoral dissertation, University of Cape Town, Cape Town.

Elo, S. \& Kyngäs, H., 2008, 'The qualitative content analysis process', Journal of Advanced Nursing 62(1), 107-115. https://doi.org/10.1111/j.1365-2648.2007.04569.x.

Franke, B. \& Zhang, L., 2016, Enforcement and managers' collective preference toward mandatory disclosure, viewed 13 January 2018, from https://ssrn.com/abstract= 2534300; https://doi.org/10.2139/ssrn.2534300. SSRN 2534300.

Gherghina, S. \& Volintiru, C., 2017, 'A new model of clientelism: Political parties, public resources, and private contributors', European Political Science Review 9(1), 115-137. https://doi.org/10.1017/S1755773915000326

Gilbert, M.D., 2012, 'Disclosure, credibility, and speech', Journal of Law \& Politics 27(4), 627-683. https://doi.org/10.2139/ssrn.1951917

Gilbert, M.D. \& Aiken, B.F., 2015, 'Disclosure and corruption', Election Law Journal 14(2), 148-164.

Gildenhuys, J.S.H., 1993, Public financial management, Van Schaik, Pretoria.

Hashmi, M., Governatori, G. \& Wynn, M.T., 2016, 'Normative requirements for regulatory compliance: An abstract formal framework', Information Systems Frontiers 18(3), 429-455.

Hassanein, A. \& Hussainey, K., 2015, 'Is forward-looking financial disclosure really informative? Evidence from UK narrative statements', International Review of Financial Analysis 41, 52-61. https://doi.org/10.1016/j.irfa.2015.05.025

Hsieh, H.F. \& Shannon, S.E., 2005, 'Three approaches to qualitative content analysis', Qualitative Health Research 15(9), 1277-1288. https://doi.org/10.1177/10497 32305276687

Independent Electoral Commission (IEC), 2016, Party funding, viewed 12 December 2016, from http://www.elections.org.za/content/Parties/Party-funding/.

Jordan, M.M., Yusuf, J.E., Berman, M. \& Gilchrist, C., 2017, 'Popular financial reports as fiscal transparency mechanisms: An assessment using the fiscal transparency index for the citizen user', International Journal of Public Administration 40(8), 625-636. https://doi.org/10.1080/01900692.2016.1186175

Kahl, A. \& Belkaoui, A., 1981, 'Bank annual report disclosure adequacy internationally', Accounting and Business Research 11(43), 189-196. https://doi.org/10.1080/000 14788.1981.9729700

Kasekende, E., Abuka, C. \& Sarr, M., 2016, 'Extractive industries and corruption: Investigating the effectiveness of EITI as a scrutiny mechanism', Resources Policy 48, 117-128. https://doi.org/10.1016/j.resourpol.2016.03.002

Kotze, D., 2004, 'Political party funding in the 2004 election', Journal of African Elections 3(2), 27-46.

Leuz, C. \& Wysocki, P.D., 2016, 'The economics of disclosure and financial reporting regulation: Evidence and suggestions for future research', Journal of Accounting Research 54(2), 525-622. https://doi.org/10.1111/1475-679X.12115

Li, D., Song, L. \& Zhang, Z., 2014, 'Does the relationship between accounting disclosure and bank loan contracts vary with borrower characteristics? Evidence from emerging markets', Asian Journal of Finance \& Accounting 6(1), 440-463. https:// doi.org/10.5296/ajfa.v6i1.5565

Licht, A.N., 2016, 'Motivation, information, negotiation: Why fiduciary accountability cannot be negotiable', in D. Gordon Smith \& A.S. Gold (eds.), Research handbook on Fiduciary Law, pp. 159-179, Edward Elgar Publishing Ltd., Northampton, MA.

Lodge, T., 1998, 'Political corruption in South Africa', African Affairs 97, 157-187.

Mail \& Guardian, 2015, Sources of party funding to remain private - Court rules, viewed 12 December 2016, from http://mg.co.za/article/2015-09-30-sources-ofparty-funding-to-remain-private.

Maphunye, K.J., 2018, 'Political party funding [Radio broadcast interview]', interviewed by J. Robbie (Host), Morning Edition, Radio 702, n.d.

Mataković, H. \& Petak, Z., 2015, 'Party finance regulation: Causes, instruments and impact', Acta Universitatis Danubius. Juridica 1, 98-114.

Nelson, P.J., 2001, 'Transparency mechanisms at the multilateral development banks', World Development 29(11), 1835-1847. https://doi.org/10.1016/S0305-750X(01) 00073-0 
News24, 2016, Local elections: Voters should know who funds, viewed 12 December 2016, from https://www.news24.com/Columnists/GuestColumn/local-electionsvoters-should-know-who-funds-parties-20160802.

Norris, P. \& Van Es, A.A., 2016, Checkbook elections?: Political finance in comparative perspective, Oxford University Press, Docklands. https://dx.doi.org/10.1093/acpr of:0so/9780190603601.001.0001

O'Regan, K., 2010, Political parties: The missing link in our constitution?, Keynote Address, Cape Town, 27 August 2010, viewed 12 March 2017, from http://www. law.uct.ac.za/sites/default/files/image_tool/images/99/Political-Parties-in-theConstitution-address-27-August-2015.pdf.

Phosa, M., 2012, Party funds not for playing politics, viewed 21 January 2017, from www.fin24.com/Economy/Party-funds-not-for-playing-politics-20120608-2.

Pinto-Duschinsky, M., 2002. 'Financing politics: A global view', Journal of Democracy 13(4), 69-86.

Potter, T., 2015, 'Buckley v. Valeo, political disclosure and the first amendment', Akron Law Review 33(1), 4.

Prest, A.R. \& Barr, N.A., 1985, Public finance in theory and practice, Weidenfeld and Nicolson, London.

Primo, D.M., 2013, 'Information at the margin: Campaign finance disclosure laws, ballot issues, and voter knowledge', Election Law Journal 12(2), 114-129. https:// doi.org/10.1089/elj.2012.0161

Republic of South Africa (RSA), 1997a, No. 71 of 1997: Non-profit Organisations Act, 1997, Government Gazette No. 18487, Government Printers, Pretoria.

Republic of South Africa (RSA), 1997b, No. 103 of 1997: Public Funding of Represented Political Parties Act, 1997, Government Printers, Pretoria.

Republic of South Africa (RSA), 2000, No. 2 of 2000: Public Access to Information Act, 2000, Government Printers, Pretoria.

Republic of South Africa (RSA), 2004, No. 25 of 2004: Public Audit Act, 2004, Government Printers, Pretoria.
Right2Know Campaign, 2015, Statement: R2K campaign supports MVC legal challenge: Voters have a right to know who funds political parties!, viewed 12 December 2016, from http://www.r2k.org.za/category/party-funding/.

Robinson, V. \& Brummer, S., 2006, 'SA democracy incorporated: Corporate fronts and political party funding', Institute for Security Studies Papers 129, 38

Rowbottom, J., 2016, 'Corruption, transparency, and reputation: The role of publicity in regulating political donations', The Cambridge Law Journal 75(2), 398-425. https://doi.org/10.1017/S0008197316000234

Sarakinsky, I., 2007, 'Political party finance in South Africa: Disclosure versus secrecy, democratization', Journal of Democratization 14(1), 111-128. https://doi.org/ 10.1080/13510340601024330

Schneider, G.T. \& Scholze, A., 2015, 'Mandatory disclosure, generation of decisionrelevant information, and market entry', Contemporary Accounting Research 32(4), 1353-1372. https://doi.org/10.1111/1911-3846.12142

Tsalavoutas, I. \& Dionysiou, D., 2014, 'Value relevance of IFRS mandatory disclosure requirements', Journal of Applied Accounting Research 15(1), 22-42. https://doi. org/10.1108/JAAR-03-2013-0021

Van Belle, S. \& Mayhew, S.H., 2016, 'What can we learn on public accountability from non-health disciplines: A meta-narrative review', BMJ Open 6(7), e010425. https://doi.org/10.1136/bmjopen-2015-010425.

Van Biezen, I., 2010, Campaign and party finance. Comparing democracies: Elections and voting in global perspective, pp. 65-94, Sage Publications, London.

Wehner, J. \& De Renzio, P., 2013, 'Citizens, legislators, and executive disclosure: The political determinants of fiscal transparency', World Development 41, 96-108. https://doi.org/10.1016/j.worlddev.2012.06.005

Zhang, J., 2015, 'Voluntary information disclosure on social media', Decision Support Systems 73(May), 28-36. https://dx.doi.org/10.1016/j.dss.2015.02.018

TutorVista.Com, 2017, How to calculate percentage increase?, viewed 03 September 2017, from http://www.tutorvista.com/content/math/how-to-calculate-percentageincrease/. 